\title{
CHOOSING THE LESSER EVIL: FORECASTING PRESIDENTIAL ELECTIONS IN PERU
}

\author{
¿Escogiendo el mal menor? Pronosticando las elecciones \\ presidenciales en Perú
}

Escolhendo o mal menor: Previsão de eleições presidenciais no Peru

\section{MOISÉS ARCE (1) marce@tulane.edu ${ }^{1}$ \\ SOFÍA VERA (10) sofiavera@ku.edu ${ }^{2}$}

\footnotetext{
${ }^{1}$ Tulane University

2 University of Kansas
}

Submission: 2021-02-18

Accepted: 2021-07-15

First View: 2021-07-29

Publication: 2022-05-31

\begin{abstract}
Keywords: forecasting; presidential elections; economic voting; Peru

Abstract

The Peruvian political landscape is dominated by the weakness of party organizations, the continuous rotation of political personalities, and, in turn, high electoral volatility and uncertainty. Nevertheless, we observe patterns of electoral competition that suggest candidates learn to capture the political center and compete over the continuation of an economic model that has sustained growth. We use this information to record the vote intention for the candidate viewed as the lesser evil. Our forecasting results predict a good share of the variation in political support for this candidate. The out-of-sample prediction also comes fairly close to the real electoral results. These findings provide some degree of electoral certainty in an area that, to date, remains understudied.
\end{abstract}




\begin{abstract}
Palabras clave: Resumen
pronosticación; El panorama político peruano está dominado por la debilidad de las organizacioelecciones presidenciales; voto económico; Perú nes partidistas, rotación continua de las personalidades políticas y, a su vez, una alta volatilidad e incertidumbre electoral. Sin embargo, observamos patrones de competencia electoral que sugieren que los candidatos aprenden a capturar el centro político y competir por la continuación de un modelo económico que ha tenido un crecimiento sostenido. Usamos esta información para registrar la intención de voto del candidato percibido como el mal menor. Nuestros pronósticos predicen una buena parte de la variación en el apoyo político a dicho candidato. La predicción fuera de la muestra también se acerca bastante a los resultados electorales reales. Estos hallazgos aportan cierto grado de certeza electoral en un área que, hasta la fecha, sigue siendo poco estudiada.
\end{abstract}

Palavras-chave: Resumo

prognóstico;

eleições

presidenciais;

voto econômico;

Peru

O cenário político peruano é dominado pela fraqueza das organizações partidárias, pela rotação contínua das personalidades políticas e, por sua vez, pela alta volatilidade e incerteza eleitoral. No entanto, observamos padrões de competição eleitoral que sugerem que os candidatos aprendem a conquistar o centro político e competir pela continuidade de um modelo econômico com crescimento sustentado. Usamos essas informações para registrar a intenção de voto para o candidato considerado o mal menor. Nossos prognósticos predizem uma grande parte da variação no apoio político a este candidato. A previsão fora da amostra também se aproxima bastante dos resultados eleitorais reais. Estes resultados fornecem certo grau de certeza eleitoral em uma área que, até o momento, permanece pouco estudada.

\section{INTRODUCTION}

When talking about elections, it is a common saying that "anything can happen in Peruvian politics." This statement reflects the poor quality of party representation in the country and the ensuing electoral volatility of the Peruvian electorate. Starting in the late 1980s, in fact, the country's party system became unglued and the political landscape is now occupied by a broad swath of political outsiders with little or no experience in government. These politicians are not supported by stable party organizations or institutions, and party identification is very weak. The uncertain political environment makes it very difficult for the Peruvian voters to evaluate incumbency for one government to the next and voters are typically drawn to making choices based on who is likely do less damage while in office.

Our analysis of presidential elections shows that candidates are keen to move to the political center to win office (what we characterize as centrism), and in a context of an expanding economy, voters have a large preference for the continuity of economic model. This economic model is anchored in market-friendly policies, which can be traced to the government of Alberto Fujimori (1990-2000) (Arce, 2005). In an environment characterized by the fluidity of political organizations 
and political personalities, voters weigh centrism and continuity, and support the candidate who is perceived to be the lesser evil.

We use polling data on vote intention from March 2000 to September 2020 to forecast the outcomes of elections in Peru. The dataset includes 181 election surveys and it is most comprehensive source on electoral polls to date. Forecasting models draw on theories of voting behavior and empirical evidence about what matters to voters when they cast their ballots (Lewis-Beck and Tien, 2012; Stegmaier and Norpoth, 2013). Building on these models, and forecasting literature in Latin America (Bunker and Bauchowitz, 2016; Turgeon and Rennó, 2012; Bunker, 2020), we seek to add some degree of certainty in an area of Peruvian politics that has remained largely unexplored.

We begin this paper by highlighting broad patterns that can be observed across the presidential elections since 2000, and the political and economic context faced by Peruvian voters. After situating this paper in the forecasting literature, we describe the data and methods we use to predict the country's presidential elections. We present our results with both monthly aggregated and disaggregated data poll data, longer lead time before elections, and alternative indicators of the national economy. The results predict a good share of the variation in political support for the candidate viewed as the lesser evil. Our out-of-sample prediction also comes fairly close to the real electoral results. We conclude this paper by discussing the implications of these findings for the study of Peruvian elections going forward.

\section{CENTRISM AND CONTINUITY}

As is commonly acknowledged, the quality of representative institutions in Peru is very low. Soon after the country's return to democracy in the 1980s, two sweeping crises - hyperinflation and political violence - took a toll on the party system, and since 1990 political outsiders and independent politicians have dominated the political scene. New parties or political movements are created in almost every electoral cycle, but these organizations do not have national reach and are disconnected from social bases. They also typically win office with fragile pluralities. Scholars view the country as a democracy without parties (Levitsky and Cameron, 2003), and further characterize the existing party system as personalistic vehicles for private, individual gains (Levitsky, 2013), not a mechanism for the implementation of broad public policies or the distribution of public goods. Hereafter, we talk about candidates or politicians, not parties.

Presidential campaigns kick off in early January and elections are scheduled in early April. A runoff follows in early June (see Table 1). The high level of electoral volatility and uncertainty places the Peruvian electorate in a very tight corner. 
However, some broad patterns can be discerned across the presidential elections since 2000 , when data on vote intention are readily available. These patterns include: (a) the emergence of front runners, (b) candidate learning and moderation to capture the political center (or centrism), as well as (c) a broad electorate preference for the continuity of the economic model. The latter two developments centrism and continuity - are the byproducts of an extended period of economic growth following a commodity boom (Arce, 2014) and the weakness of the Peruvian political class (Vergara and Encinas, 2016). ${ }^{1}$

First, there was a clear frontrunner in some of these electoral contests. For instance, Alejandro Toledo had previously run for office in the highly controversial presidential elections in 2000 , which followed the abrupt fall from power of Alberto Fujimori. Toledo occupied the political center and become the clear frontrunner in the 2001 presidential contest. The 2001 contest was thus a race for the second place (or runoff). Polls showed a three-way tie for the second spot among Fernando Olivera (13\%), Lourdes Flores Nano (12 \%) and former President Alan García (12 \%) (Schmidt, 2003). Similarly, in the presidential elections of 2016, Keiko Fujimori-the daughter of Alberto Fujimori-enjoyed consistent support from approximately a third of the electorate, and these elections also become contest for the second place. The Jurado Nacional de Elecciones (JNE) disqualified two candidates in early March of that year - well after the campaign had already started - and by early April, Pedro Pablo Kuczynski and Verónica Mendoza were on a statistical tie for the second spot (Schmidt, 2016).

However, the presidential elections of 2006 and 2011 were more uncertain, but consistent with the electoral volatility of the Peruvian electorate. For instance, in October 2005, six months before the presidential election of 2006, polls showed Flores Nano as the clear frontrunner (Schmidt, 2007). But support for Ollanta Humala began to rise in January 2006 and García's support peaked at the very end of the campaign. Both Humala and García went on to meet in the June runoff. The early rise of Flores Nano was attributed to polling error as most public opinion polls are drawn from Lima, where her support was the strongest (Schmidt, 2007). In the same way, in 2010 several polls predicted a tight race between Luis Castañeda and Keiko Fujimori, and showed little support for Humala. However, Humala had a very late surge and became a clear frontrunner by early April, just days before the election (Schmidt, 2012). He emerged first in the first round ( $31.7 \%$ of valid votes) and won the presidency during the runoff $(51.4 \%)$.

Second, there is ample evidence of what may be characterized as candidate learning and moderation to occupy the political center of the ideological spectrum.

1. The authors understand a political class to be weak when political parties do not receive a significant percentage of the vote; elected authorities have short tenures; and political vehicles and their leaders are disconnected from social bases (Vergara and Encinas 2016, 163). 
As shown in Table 1, and based on the electoral results of the first-round elections, several of the top presidential contenders reappear in subsequent elections. But candidate García of 2001 is different from then President García of 2006, and candidate Humala of 2006 is also different from then President Humala of 2011, just to name a few examples.

Table 1. Top Presidential Contenders and Dates of the Elections, 2001-21

\begin{tabular}{lllll}
\hline \multicolumn{1}{c}{ Elections 2001 } & \multicolumn{1}{c}{ Elections 2006 } & Elections 2011 & \multicolumn{1}{c}{ Election 2016 } & Elections 2021a \\
\hline Toledo & Humala & Humala & Fujimori & Forsyth \\
García & García & Fujimori & Kuczynski & Mendoza \\
Flores Nano & Flores Nano & Kuczynski & Mendoza & Lescano \\
Olivera & Chávez & Toledo & Barnechea & Fujimori \\
Boloña & Paniagua & Castañeda & García & de Soto \\
\hline April 8, 2001 & April 9, 2009 & April 10, 2011 & April 10, 2016 & April 11, 2021 \\
June 3, 2001 & June 4, 2006 & June 5, 2011 & June 5, 2016 & June 6, 2021 \\
\hline
\end{tabular}

Notes: Candidates are listed based on their share of valid votes from the first round of the electoral contest. Names in italics faced each other in the runoff. Names in bold won the runoff.

(a) Top presidential contenders based on vote intention (La República, 2021)

(b) Dates in this row are the dates of the first-round elections.

(c) Dates in this row are the dates of the runoffs.

Source: Authors' own elaboration based on data from ONPE (2021).

In 2001, for instance, García returned to Peru after a nine-year exile abroad, and only after the Supreme Court lifted his arrest warrant. He arrived in the country in late January 2001, just a few months before the April 8 contest. García emerged as a staunch critic of Fujimori's neoliberal policies and his authoritarian style (Schmidt, 2003). During the electoral campaign, the Peruvian electorate were frequently reminded of the many social and economic hardships suffered during his first presidency in 1985. Annual inflation, for example, reached a historical record of 7,649 percent in 1990, and political violence from guerrilla groups, such as Sendero Luminoso (SL) and the Movimiento Revolucionario Tupac Amaru (MRTA), rose considerably. The 1980s in Peru were aptly described as "a national trauma" (Leiteritz, 2010). In 2006, however, García was a different candidate. He "stressed that he had learned the value of responsible economic policies from past 
mistakes" (Schmidt, 2007, p. 816). He also "offered qualified support for the free trade agreement [with the United States], highlighted a scheme to stimulate agricultural exports from the Andes, and promised to defend the weak from vagaries of the market" (Schmidt, 2007, p. 816).

A more pronounced change came from Humala, a former military officer who staged an armed uprising in southern Peru against the government of Alberto Fujimori. In 2006, Humala, a political outsider, toed closely the Chavista line (after Venezuela's Hugo Chávez). In the campaign trail, for instance, he "praised the nationalist, left-leaning dictatorship of Juan Velasco (1968-1975), called for a stronger state role in the economy, vowed to halt the eradication of coca, and opposed ratification of the recently negotiated free trade agreement with the United States" (Schmidt, 2007, pp. 815-816). In early January 2006, he visited Venezuela and meet with Hugo Chávez. Like Chávez, Humala "promised to convoke elections for a constitutional convention, oversee the drafting of a new charter, and then hold elections for a new Congress" (Schmidt, 2007, p. 816). But in 2011, Humala dropped his views favoring economic nationalism entirely and sought to reassure voters his commitment to democratic norms and practices. As Schmidt (2012, p. 627) writes, Humala "went to extraordinary lengths to moderate his image still further, promising consensus building, economic stability, and gradualism." He also "took a public oath not to seek re-election and to respect the constitution, the division of powers, the legal order, civil liberties, and human rights" (Schmidt, 2012, p. 627). In brief, whereas the Humala of 2006 aligned himself with Venezuela's Hugo Chávez, the Humala of 2011 was different and now sided with Brazil's moderate Luiz Inácio Lula da Silva (Schmidt, 2012). In the words of Lupu (2012, p. 622), Humala "even replaced the red shirts he had worn in the earlier campaign with a suit and tie." The red shirts were a nod to Chavismo. After winning the runoff, Humala "went on a foreign tour that pointedly omitted Venezuela" (Lupu, 2012, p. 623).

Keiko Fujimori also took some steps toward moderation, but the legacy of her father, Alberto Fujimori, remains a large shadow. During the 2011 electoral contest, she initially considered pardoning her father's conviction for corruption and human-rights abuses, but later backed away from this idea (Schmidt, 2012). She admitted that her father had made some mistakes, but at the same time referred to him as "Peru's best president" (Lupu, 2012, p. 623). She argued that she would be more effective than Humala in combating crime, but late in the runoff, Jorge Trelles, a spokesperson for her campaign, defended her father's record by stating: "We killed fewer people than other governments" ("Nosotros matamos menos que otros gobiernos") (Schmidt, 2012, p. 627). ${ }^{2}$ In the 2016 presidential election,

2. Fujimori recruited former New York City Mayor Rudy Giuliani as an advisor on public safety. 
she made a bold move and "vetoed over half of her party's incumbent members of Congress from seeking re-election, including several who were strongly associated with her father" (Schmidt, 2016, p. 451). She criticized her father's decision to run for reelection in 2000 . She also promised, once again, not to pardon him and embraced the findings of the Truth and Reconciliation Commission that were critical of his government (Schmidt, 2016).

Third, and finally, candidate learning and moderation reflects a broad preference for continuity by the Peruvian electorate. Voters weigh which candidate most aptly captured the political center (centrism) and who was perceived to do the less damage while in office by embracing continuity. ${ }^{3}$ Centrism and continuity work well across the presidential elections, save for 2011. In virtually all of the runoffs, Peruvians faced a stark choice (and reality), and the runoffs have become increasingly tighter over time (see Figure 1). In 2001 runoff, for example, many Peruvians disliked Toledo and García, and some journalists went even further and asked Peruvians to cast spoiled or blank ballots in the runoff (Schmidt, 2003, p. 349). Heeding this call, polls showed an increase for the abstention option between late March and early April. Polls also showed a tight race, and near the end of the campaign, it appeared that García was in front of Toledo. As Schmidt (2003, p. 350) writes, the "prospect of another García presidency triggered a major shift from the abstention option to Toledo in the final week, which may well have been decisive." In the end, Peruvians "resigned themselves to voting for the one deemed to be the lesser of the two evils" (Schmidt, 2003, p. 350).

Figure 1. Share of Valid Votes in the Runoffs, 2001-2016

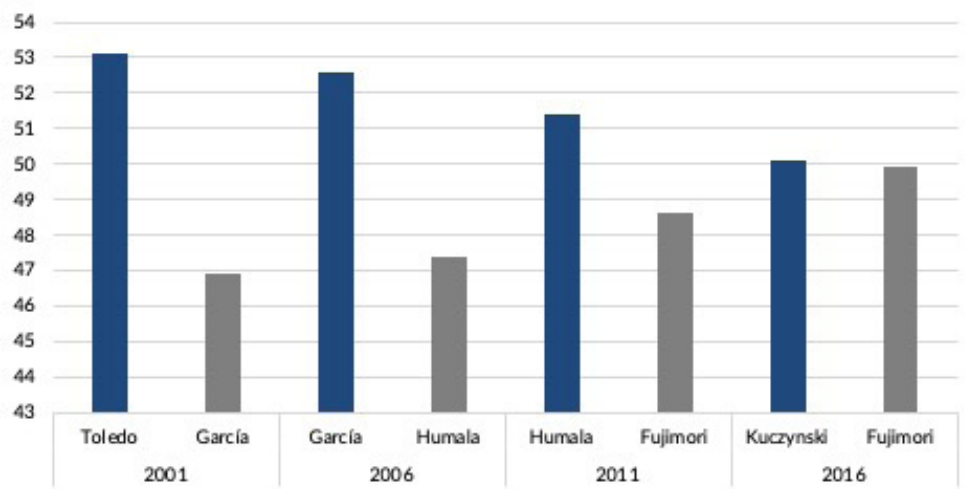

Source: Authors' own elaboration based on data from ONPE (2021).

3. To clarify, we don't see centrism and continuity as two separate, unrelated conditions. See also Tanaka (2011), and Dargent and Muñoz (2016). 
The 2006 runoff between García and Humala was also seen "as a choice between two very flawed candidates" (Schmidt, 2007, p. 818). With the benefit of candidate learning and moderation, García now advocated for "responsible change," and aptly moved to the center of the political spectrum (Schmidt, 2007, p. 817). Humala, in contrast, was widely perceived as the anti-establishment candidate, following Chavismo and even running a campaign with covert financing by Hugo Chávez (Schmidt, 2007, p. 816).

Turning to the 2011 electoral contest, three candidates competed for the "mantle of continuity" of the economic model (Kuczynski, Toledo and Castañeda), but none of them made it to the runoff (Lupu, 2012, p. 621). Had it been for stronger parties, these three candidates could have produced a single ticket with better odds to win the election (Bril-Mascarenhas, 2012). Instead, their lack of coordination led to a runoff between Humala on the left of the political spectrum and Fujimori on the right. Mario Vargas Llosa, Peru's Nobel Prize winning novelist, depicted the runoff as a choice "between Aids and cancer."

In the runoff, both candidates moved quickly to court moderate votes (Lupu, 2012, p. 623). Humala softened his rhetoric. He also "took on some of Toledo's economic advisors and courted the former president's tacit endorsement" (Schmidt, 2012, p. 623). Fujimori admitted "mistakes" made by his father (Lupu, 2012, p. 623) and picked up the endorsements of Kuczynski, Castañeda, and even García (Schmidt, 2012, p. 623). Keiko represented greater continuity to the economic model and was expected to follow the pro-business policies of her father (Lupu, 2012, p. 622). Humala, in contrast, "made promises to redistribute the fruits of Peru's economic growth and resource wealth" (Lupu, 2012, p. 624). Humberto Speziani, the president of CONFIEP, Peru's largest business group, described Humala as an individual who "has a lot of social sentiment" ("tiene bastante sentimiento social") (Ponce Acuña, 2011). Humala wanted to reduce extreme poverty, but business leaders were concerned about the impact of these policies on economic growth.

When the votes were counted, Humala won the election. Levitsky notes that "Humala was more successful than Fujimori in moderating his discourse to reach the center of the political spectrum" (quoted in Bril-Mascarenhas, 2012, p. 13). Levitsky adds, notwithstanding "the steady economic growth that marked Peru's neoliberal years, its citizens chose to turn to the candidate that was furthest away from economic orthodoxy" (quoted in Bril-Mascarenhas, 2012, p. 13). ${ }^{4}$ Lima's stock exchange plunged $12.51 \%$ after Humala's second-round victory (RPP, 2011).

4. Schmidt (2012, p. 628) also writes: "Humala skillfully calibrated a reformist message that mobilised his base while allowing him to broaden his appeal in the runoff." 
The emergence of front runners, the supply of centrism by candidates and the demand for continuity by Peruvian voters are three broad patterns that can be observed across the presidential elections since 2000. A runoff with centrism and continuity is a delicate balance and these conditions operated well across the presidential elections, save for 2011. In that election, Humala offered centrism, but failed on continuity. Keiko Fujimori, in contrast, was a sure bet on the continuity of the economic model, but came short on centrism.

\section{ECONOMIC EXPANSION AND WEAK PARTIES}

An extended period of economic expansion driven largely by a commodity boom (Arce, 2014) as well as the weakness of political personalities and parties (Vergara and Encinas, 2016) can help to explain centrism and continuity. First, the economic expansion generated an improved standard of living for all segments of the population. Peru's GDP per capita more than doubled between 1990 (the start of the government of Alberto Fujimori) and 2019 from $\$ 2,650$ to $\$ 6,480$ (constant 2010 US\$) (World Bank, 2021). The percentage of the population living in poverty declined from $48.5 \%$ in 2004 to $27.7 \%$ in 2017 . Those living in extreme poverty dropped from $17.4 \%$ in 2004 to $3.8 \%$ in 2017 (Arce and Incio, 2018). The unprecedented economic expansion influenced a consumer-oriented mindset among the country's growing middle class. To be clear, the "Peruvian miracle" (Mendoza, 2013) was a stark departure from the economic populism and disaster of the 1980s. If there was something Peruvian voters feared the most, it was a redo of that "national trauma" (Leiteritz, 2010).

Second, the weakness of the Peruvian political class is another factor behind centrism and continuity. Even though Humala in 2011 aptly moved to occupy the political center through candidate learning and moderation, he represented the greatest threat to the continuity of the economic model. Vergara and Encinas (2016, p. 160) described him as a "fierce antiestablishment radical." But Humala won the election without a party, having no previous experience in government, as well no strong business support. This vacuum made him vulnerable to empowered technocrats and bureaucrats within the state, particularly the Ministerio de Economía y Finanzas (MEF) and the Banco Central de Reserva del Perú (BCRP) (Dangert, 2012). Vergara and Encinas (2016, p. 160) argue that Humala did not embrace neoliberalism ideologically, but yet embraced it in practice. In the wake of his second-run victory, and to appease markets, Humala recruited former officials from both Toledo and García to key economic positions (Schmidt, 2012; Lupu, 2012). It also took him more than twenty days to find a suitable Minister of Economy. He appointed Luis Miguel Castilla, who was García's vice-minister 
of economy. In this way, Humala ensured the continuity to the economic model, albeit after the election (Vergara and Encinas, 2016).

Overall, and compared to neighboring countries like Bolivia and Ecuador that sought to advance "postliberal" economic regimes, the market economic model left by Alberto Fujimori remains largely intact. Cotler (2011, p. 546) criticized Toledo for setting the economy on "cruise control" as his government kept the same economic policies as Fujimori's. García arguably sought to push neoliberalism even further by opening the Amazon rainforest for development (Arce, 2014). Kuczynski was the quintessential insider or establishment candidate. He was a manager from the Central Bank during the first Belaúnde government (1963-68) and then served as Minister of Energy and Mines during his second government (1980-85). He was also a former official of the International Monetary Fund and World Bank, and later served as Toledo's Minister of Economy and Finance and then Prime Minister. He defeated Keiko Fujimori in the runoff of 2016-the difference in votes was 41,057.

The weakness of the party representation, in particular, and political class, in general, makes election forecasting in Peru a toll order. All of the former Presidents since 1990 (Fujimori, Toledo, García, Humala, Kuczynski and Vizcarra) were ousted from office or imprisoned on allegations of corruption over the past three decades. $^{5}$ In the 2016 elections, Gregorio Santos, the former governor of Cajamarca, run his campaign from prison and was granted a special furlough to participate in the presidential debate (Schmidt, 2016, p. 452). Keiko Fujimori, who ran for president in 2011 and 2016, also served time in prison for money laundering and obstructing justice. In the presidential contest of 2021, both Keiko Fujimori and former President Humala ran for office again. In this election, and up until February 2021, George Forsyth was the top presidential contender (see Table 1) (O'Boyle, 2020). He is a former goalkeeper and mayor of the populous district of La Victoria in Lima. Then polls on or around March 2021 revealed Yonhy Lescano as the frontrunner. On election night, however, neither Forsyth nor Lescano emerged victorious. ${ }^{6}$

By now, we have established that candidates often move to the political center to win office (centrism) and voters' preference for the continuity of the economic model is related to the economic expansion the country enjoyed during most of the 2000s and 2010s. The weakness of the political class also moves politicians without parties like Humala to embrace this continuity. This does not suggest that other voter concerns don't matter. In the 1980s and early 1990s, in

5. Martín Vizcarra took over after Kuczynski was ousted from office, but in late 2020, Vizcarra was also removed from office over allegations of corruption.

6. As of this writing, the 2021 presidential election was also described as a vote for the lesser evil. See Freeman and McClintock (2021). 
fact, security concerns as a consequence of rising political violence in Peru were paramount, and voters rated presidents differently based on who they perceived to be more effective in containing violence (Arce, 2003). But in this period of study - the 2000s and 2010s - and in a context of overall pacification, these security concerns faded considerably. While electoral volatility and uncertainty remain a salient feature in Peruvian politics, we can draw on existing models of voting behavior to forecast the outcomes of elections. We turn to this literature next.

\section{FORECASTING ELECTIONS IN LATIN AMERICA AND PERU}

Bunker and Bauchowitz (2016, p. 209) describe the state of electoral forecasting in Latin America as "incipient" because of the relatively young age of Latin American democracies as well as the quality of available data. As the authors (2016, p. 213) write: "Electoral forecasting cannot take place in systems without elections or in environments with incomplete information." To address these limitations and make valid election forecasts, some authors have embraced betting markets (Bunker and Bauchowitz, 2016), while others have recommended the use of subnational data, particularly when the number of elections under study is very small (Turgeon and Rennó, 2012). Betting markets provide forecasts of electoral results based on the buying and selling of candidate futures with real money (Stegmaier and Norpoth, 2013) and provide continuous data points to forecast elections, as in Chile's Bolsa Electoral (Bunker and Bauchowitz, 2016). Turgeon and Rennó (2012, p. 807) produced a forecast model for Brazil using four presidential elections (1994, 1998, 2002 and 2006) for the 27 states that comprise the Union (generating a sample of 108 observations - 27 states $x$ four years). In addition, Cantú, Hoyo and Morales (2015) combined poll aggregation methods with dynamic linear models to forecast presidential elections in Mexico. To our knowledge, studies on electoral forecasting in Peru are rare, but Bunker (2020) proposed a two-stage model to combine polls that produced relatively accurate predictions for Latin American elections and correctly forecasted the placement of candidates in the Peruvian 2016 election. While making important contributions, the volatile nature of the Peruvian electoral scene requires greater attention.

To forecast when the lesser evil will win in a country like Peru, where "incumbent party" is a meaningless concept for forecasting, we build on dominant scientific approaches in the field (see the reviews in Lewis-Beck and Tien, 2012; and Stegmaier and Norpoth, 2013). As Lewis-Beck (2005) presented it, the standard political economy model of voting takes the generic form: election result $=f$ (government support, economic growth). The vote is therefore a function of two core components: a political factor capturing the general mood of the population regarding the outgoing administration's performance and an economic factor 
measuring the overall strength of the national economy. This basic model is derived from robust theories explaining vote choice (Fiorina, 1981; Lewis-Beck and Stegmaier, 2007).

While forecasting models with this basic structure generally predict presidential outcomes fairly well, they have not been widely applied to Latin American democracies. As a result, we do not know if support for the lesser evil in Peru will follow the standard political economy model. Since this model is essentially a referendum on how well the current government is handling economic and noneconomic issues, we argue that the lesser evil will benefit from the incumbent government's good performance. Other things being equal, therefore, the better the performance of the economy and the better the popularity of the incumbent president, the better the lesser evil candidate will do. Given the large number of unknowns in forecasting Peruvian elections, we have chosen to use the most theoretically-grounded predictors and the most parsimonious model.

\section{DATA AND METHODS}

To estimate the vote for the lesser evil, we use polling data from March 2000 to September 2020. We collected 181 election surveys in which a vote intention question was asked and constructed a continuous series with consistent question wording. These polls usually adopt the standard question wording: "If the general elections were held tomorrow, which candidate would you vote for."7 To our knowledge, this is the first time that a dataset of pre-electoral polls spanning twenty years has ever been compiled for Peruvian elections. ${ }^{8}$ We provide descriptive statistics of our variables, including the number of months and polls per election cycle, in the Appendix.

We decided to base our predictive models on vote intention because young democracies like Peru's have a very short history of democratic elections. While forecasting models in advanced democracies - such as the US - generally examine aggregate time series from WWII to the present, Peru has a very small sample size of national elections. Thus, forecasting models cannot be estimated using past election results (Stegmaier and Williams, 2016). To overcome the problem of too few data points, popularity functions with monthly time series data of party

7. In Spanish, the wording is: "Si mañana fueran las elecciones presidenciales, ¿por quién votaría usted?"

8. Our data cover five elections: 2000, 2001, 2006, 2011, 2016, and 2021 (up to September 2020). While the vote intention time series could potentially span 246 months, we only have information for 84 months, given that polling houses typically publish vote intention data only in the months leading up to the election day. See table A2 in the Appendix. 
support are an available option that has been used previously to forecast elections in Hungary and the UK (Sanders, 2005; Stegmaier and Lewis-Beck, 2009; Stegmaier and Williams, 2016). In this paper, we adopt this approach.

We aggregate raw poll numbers to create monthly summary measures of vote intention. By doing so we hope to overcome some of the limitations of relying on an individual single poll. ${ }^{9}$ Among the numerous challenges of working for polling data, the poor quality of data is one of the most serious concerns. ${ }^{10}$ Some polling houses, for instance, are known or suspected of favoring one political party over another (Williams and Reade, 2016). Other polling houses are not transparent about their sampling methodology. Moreover, given that polling data are not always nationally representative, urban and affluent individuals might be overrepresented in poll samples. We assume, therefore, that each poll is a slightly flawed measure of the real support for a party at a given point in time. To address these limitations and biases, we thus run our models with the average percentage of voters intending to vote for a candidate. Then, we compare these results to models using disaggregated data and a subset of data from the most reliable polling sources. ${ }^{11}$

\section{Dependent variable}

In attempting to forecast the electoral results in multiparty elections with high levels of volatility, one of the greatest challenges is the difficulty in dealing with the large number of active players and the frequent emergence of new actors (Walther, 2015). We cannot simply use incumbent party vote share as our dependent variable, like forecasting models in advanced democracies do. We can, however, identify the candidates who moved to occupy the political center and embraced the continuity of the economic model. In the case of Peru, candidate learning and moderation shifts political personalities to the center, and some are more successful than others. Some of these candidates also share a similar ideological preference for the prevailing economic model, but not others. In our analysis, therefore, our dependent variable is vote intention for the lesser evil. This is calculated as the average percent of respondents supporting centrist candidates

9. As Bunker $(2020,1409)$ put it "it is likely that the average of the two polls will be a better estimator of the parameter of interest than any poll chosen at random."

10. See Serrano and Navarro (2017) for an account of the scrutiny that polls in Latin America have faced in recent years.

11. While monthly aggregated poll data might represent an improvement over raw poll numbers, these estimates might still succumb to the well-kwon urban bias in Peruvian polls, so we should use caution when interpreting the estimates in forecasting models of this nature. 
who embraced the continuity of the economy model. These candidates are: Toledo in 2001, García in 2006, Fujimori in 2011, and Kuczynski in 2016. ${ }^{12}$ These certainly are candidates with vastly different political outlooks but we contend that they share a similar distaste for radical changes to the economic model.

\section{Independent variables}

Following standard political economy models of voting (Lewis-Beck, 2005), we selected two predictors or independent variables: government popularity and economic performance. To measure government popularity, we use monthly data on presidential approval. The data was gathered from Ipsos-Peru monthly reports on presidential approval, which regularly ask respondents the following question "In general, would you say that you approve or disapprove of the president [name]'s administration?"13 To measure the strength of the national economy, we use an indicator of GPD growth collected from the Instituto National de Estadística $e$ Información-INEI (2021). There is no agreement on what is the best indicator of the state of the economy. Some scholars rely on objective measures (Stokes et al., 1997), and others on subjective perceptions (Kelly, 2003). While subjective economic evaluations tend to be the most popular economic indicator (Stegmaier and Lewis-Back, 2013; Anderson, 2000; Bartels and Zaller, 2001), a consistent monthly time series of retrospective national evaluation is not available in Peru. We thus complement these monthly data with two alternative measures: mining GPD growth and inflation. Both monthly figures come from the Banco Central de Reserva del Peru-BCRP (2021).

\section{Estimation method}

To estimate our lesser evil support models, we use simple linear regression models with lagged predictors. Given that forecasting models with longer lead time are more interesting and meaningful (Lewis-Beck, 2005), we estimate models with 1-, 2- and 3-month lags. We decided to limit our lags to 3 months only because of the short length of presidential campaigns in the country. This lag

12. We have shown that candidate moderation and learning is pivotal to capture the political center, and even though these four candidates have vastly different political backgrounds, they all moved toward centrism. What's more, Toledo (2001), García (2006), Fujimori (2011), and Kuczynski (2016) all embraced the continuity of the economic model at the time of the election, but Humala (2011) did not. 13. In Spanish, the wording is: "En general, ¿diría que aprueba o desaprueba la gestión del president [nombre del presidente]?" 
structure means that, for example, we use data from up to 3 months prior to the pre-election survey to predict the average lesser evil support in a given month. Notice that our models are dynamic and can theoretically go as far back in time as data is available. Nevertheless, few polling houses in Peru release vote intention data prior than six months before the election day, as the pool of candidates is still uncertain early in the campaign. Taking all these factors into account, we expect that models with data from one or two months prior to the pre-electoral survey will provide the best predictions. ${ }^{14}$

An important step in forecasting is evaluating the performance of the forecasting models. To compare the accuracy of the models, we use a resampling technique called cross-validation. The idea of cross-validation is to use a subset of observations to fit a model (called "training set"), and use the held-out observations to estimate the accuracy of the model (called "testing set"). The process is repeated multiple times and the results are aggregated and summarized. Given the small size of our sample, we prefer to use leave-one-out cross-validation (LOOCV) over 5 or 10 -fold cross-validation, because with LOOCV the training set would contain n-1 observations, almost as many as in the entire dataset (James et al., 2013; Kuhn and Johnson, 2013). This technique will therefore allow us to assess the relative predictive power of our models.

Finally, we replicate the analysis with disaggregated poll data to check if predictions using monthly aggregated summaries of the lesser evil support represent an improvement over raw poll data. The disaggregated dataset consists of the vote intention for the lesser evil candidate as reported per each individual poll. Another approach could have been increasing the number of observations subnationally, as in Turgeon and Rennó (2016). However, we faced serious data limitations with producing such estimation. Furthermore, to account for different pollster quality, we compare these results to models using a subset of data from the most reliable polling firm.

\section{RESULTS}

Table 2 presents the models for the lesser evil support. In each model, the support for the lesser evil was regressed on political and economic predictors measured one, two, and three months before the pre-election survey month. We observe that, consistently across the three models, presidential approval is significantly associated with support for the lesser evil, whereas economic performance is not. The positive sign of the presidential approval coefficient indicates that the

14. For a discussion about the trade-off between accuracy and lead time, read Jennings et al. (2020). 
better the presidential approval is doing, the higher the vote intention for the lesser evil. Interestingly, the effect of GDP growth on lesser evil support appears to be positive too, but the relationship is not statistically significant.

Next, we report the fit statistics, which are important for forecasters. Using cross-validation to compute out-of-sample prediction errors helps us gauge how the models perform in a held-out sample. Notice that these fit statistics are more conservative than the in-sample errors (also reported in Table 2). As expected, the model with one-month lag predictors is the strongest. Using only two indicators, the model manages to predict 42 percent of the variation in lesser evil support, which is a fair level of accuracy given the data limitations. Yet, the predicting error of 7.9 indicates that the predictive capacity of the model is somewhat weak.

Table 2. Lesser evil support models

\begin{tabular}{lccc}
\hline & $\begin{array}{c}1 \text { month } \\
\text { lag }\end{array}$ & $\begin{array}{c}2 \text { months } \\
\text { lag }\end{array}$ & $\begin{array}{c}3 \text { months } \\
\text { lag }\end{array}$ \\
\hline Presidential approval & $\begin{array}{c}0.457^{* * *} \\
(-0.08)\end{array}$ & $\begin{array}{c}0.406^{* * *} \\
(-0.1)\end{array}$ & $\begin{array}{c}0.383^{* *} \\
(-0.11)\end{array}$ \\
GDP growth & 0.351 & 0.298 & 0.033 \\
& $(-0.32)$ & $(-0.36)$ & $(-0.43)$ \\
\hline Constant & 7.26 & $9.958^{*}$ & $12.584^{* *}$ \\
\hline N & $(-3.69)$ & $(-4.01)$ & $(-4.5)$ \\
R-Square & 38 & 38 & 38 \\
RMSE & 0.552 & 0.349 & 0.266 \\
CV R-Square & 7.066 & 8.512 & 9.04 \\
CV RMSE & 0.423 & 0.247 & 0.068 \\
\hline
\end{tabular}

Significance levels: ${ }^{*} p<0.05,{ }^{* *} p<0.01,{ }^{* * *} p<0.001$ (two-tailed). Standard errors in parentheses.

Observations correspond to poll data for the 2001, 2006, 2011, and 2016 elections.

Source: Authors' own elaboration

To check if monthly aggregated poll data represents an improvement over raw poll numbers, we run the same models with disaggregated data. The results are presented in Table 3. Models 1-3 correspond to results using all available polling data, and models 4-6 present the result using only a subset of the most reliable 
polling data. These models yield very similar results and slightly more accurate predictions. We observe again that presidential approval is the best predictor of support for the lesser evil, and the model with the shortest time lead (one month) is the strongest. In these shortsighted models, the $r$-squared values range from 61.1 percent when using all available polls to 49.6 percent when using the most reliable polls only. In addition, while the economic indicator does not reach statistical significance, the relationship appears to be positive in the models with one-month lagged predictors. That is, the higher GDP growth, the higher the vote intention for the lesser evil.

Table 3. Lesser evil support models with disaggregated data

\begin{tabular}{lcccccc}
\hline & \multicolumn{3}{c}{ All polls } & \multicolumn{3}{c}{ Only lpsos polls } \\
\cline { 2 - 7 } & $\begin{array}{c}1 \text { month } \\
\text { lag }\end{array}$ & $\begin{array}{c}2 \text { months } \\
\text { lag }\end{array}$ & $\begin{array}{c}3 \text { months } \\
\text { lag }\end{array}$ & $\begin{array}{c}1 \text { month } \\
\text { lag }\end{array}$ & $\begin{array}{c}2 \text { months } \\
\text { lag }\end{array}$ & $\begin{array}{c}3 \text { months } \\
\text { lag }\end{array}$ \\
\hline $\begin{array}{l}\text { Presidential } \\
\text { approval }\end{array}$ & $0.419^{* * *}$ & $0.327^{* * *}$ & $0.259^{* * *}$ & $0.457^{* * *}$ & $0.381^{* * *}$ & $0.231^{*}$ \\
& $(-0.04)$ & $(-0.05)$ & $(-0.06)$ & $(-0.07)$ & $(-0.08)$ & $(-0.1)$ \\
GDP growth & 0.283 & -0.049 & -0.327 & 0.182 & -0.087 & -0.436 \\
& $(-0.19)$ & $(-0.2)$ & $(-0.22)$ & $(-0.3)$ & $(-0.32)$ & $(-0.36)$ \\
\hline Constant & $8.887^{* * *}$ & $14.325^{* * *}$ & $18.209^{* * *}$ & $8.265^{*}$ & $13.398^{* * *}$ & $20.556^{* * *}$ \\
& $(-2.13)$ & $(-2.2)$ & $(-2.43)$ & $(-3.64)$ & $(-3.73)$ & $(-4.23)$ \\
\hline N & 113 & 113 & 113 & 59 & 59 & 59 \\
R-Square & 0.632 & 0.427 & 0.337 & 0.541 & 0.356 & 0.169 \\
RMSE & 5.735 & 7.156 & 7.697 & 7.275 & 8.619 & 9.79 \\
CV R-Square & 0.611 & 0.394 & 0.309 & 0.496 & 0.299 & 0.106 \\
CV RMSE & 5.820 & 7.266 & 7.759 & 7.438 & 8.781 & 9.934 \\
\hline
\end{tabular}

Significance levels: ${ }^{*} p<0.05,{ }^{* *} p<0.01,{ }^{* * *} p<0.001$ (two-tailed). Standard errors in parentheses.

Observations correspond to poll data for the 2001, 2006, 2011, and 2016 elections.

Source: Authors' own elaboration

To further explore the effect of economic performance on lesser evil support, we re-run our models with alternative national economy indicators: mining GPD 
growth and inflation. Table 4 presents the results. Again, presidential approval is the strongest and most consistent predictor of support for the lesser evil. In contrast, the effect of the strength of the national economy proxied by mining production and inflation is not consistently related to support for the lesser evil. While this finding is unexpected, there are two possible explanations for the inconsistent effect of the economy. First, it is possible that subjective measures of the state of the economy could have performed better than the objective measures that we employ here; but unfortunately, a consistent monthly series of subjective economic evaluations is not available in Peru.

Table 4. Lesser evil support models with alternative economic indicator

\begin{tabular}{|c|c|c|c|c|c|c|}
\hline & \multicolumn{2}{|c|}{ Mining GPD Growth } & \multicolumn{3}{|c|}{ Inflation } & \multirow[b]{2}{*}{$\begin{array}{l}3 \text { months } \\
\text { lag }\end{array}$} \\
\hline & 1 month & $\begin{array}{l}2 \text { months } \\
\text { lag }\end{array}$ & $\begin{array}{l}3 \text { months } \\
\text { lag }\end{array}$ & 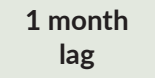 & $\begin{array}{c}2 \text { months } \\
\text { lag }\end{array}$ & \\
\hline $\begin{array}{l}\text { Presidential } \\
\text { approval }\end{array}$ & $\begin{array}{c}0.373^{* * *} \\
(-0.03)\end{array}$ & $\begin{array}{c}0.357^{* * *} \\
(-0.04)\end{array}$ & $\begin{array}{c}0.339^{* * *} \\
(-0.05)\end{array}$ & $\begin{array}{c}0.373^{* * *} \\
(-0.03)\end{array}$ & $\begin{array}{c}0.333^{* * *} \\
(-0.04)\end{array}$ & $\begin{array}{c}0.312^{* * *} \\
(-0.04)\end{array}$ \\
\hline $\begin{array}{l}\text { Mining GDP } \\
\text { Growth }\end{array}$ & $\begin{array}{l}0.028 \\
(-0.06)\end{array}$ & $\begin{array}{l}0.126 \\
(-0.10)\end{array}$ & $\begin{array}{l}0.108 \\
(-0.12)\end{array}$ & & & \\
\hline Inflation & & & & $\begin{array}{l}4.276 \\
(-2.59)\end{array}$ & $\begin{array}{l}3.338 \\
(-3.27)\end{array}$ & $\begin{array}{l}8.403^{*} \\
(-4.00)\end{array}$ \\
\hline Constant & $\begin{array}{c}11.452^{* * *} \\
(-1.21)\end{array}$ & $\begin{array}{c}12.423^{* * *} \\
(-1.72)\end{array}$ & $\begin{array}{c}13.632^{* * *} \\
(-2.20)\end{array}$ & $\begin{array}{c}10.281^{* * *} \\
(-1.33)\end{array}$ & $\begin{array}{c}13.017^{* * *} \\
(-1.49)\end{array}$ & $\begin{array}{c}13.522^{* * *} \\
(-1.52)\end{array}$ \\
\hline $\mathrm{N}$ & 113 & 113 & 113 & 113 & 113 & 113 \\
\hline R-Square & 0.625 & 0.434 & 0.329 & 0.634 & 0.432 & 0.350 \\
\hline RMSE & 5.79 & 7.111 & 7.746 & 5.724 & 7.125 & 7.622 \\
\hline CV R-Square & 0.598 & 0.394 & 0.283 & 0.608 & 0.400 & 0.321 \\
\hline CV RMSE & 5.912 & 7.269 & 7.911 & 5.842 & 7.229 & 7.692 \\
\hline
\end{tabular}

Significance levels: ${ }^{*} p<0.05,{ }^{* *} p<0.01,{ }^{* * *} p<0.001$ (two-tailed). Standard errors in parentheses.

Source: Authors' own elaboration 
Second, it is possible that the lesser evil candidate is not assigned responsibility for the state of the economy, even if their candidacy represents continuity with the incumbent's economic policies. Stegmaier and Lewis-Beck (2009), for example, argue that economic voters in Hungary were more policy-oriented than incumbency-oriented in the early elections of the post-communist era. Therefore, socialist parties were favored for its economic policies during bad economic times, even if they were in office. A similar policy-oriented economic vote could be present in Peru, where a substantive part of the electorate is consistently supporting the market friendly candidates who, in their eyes, represent the lesser evil that would contain the potential risks of abandoning the economic model. ${ }^{15}$

Finally, since our main forecasting target are the actual election results, we now compare our out-of-sample prediction of the lesser evil support to the real vote share the lesser evil took in the 2011 and 2016 elections. Did the model forecast the outcome? Table 5 presents the results. Since our vote intention data come from surveys mostly conducted in Lima, we compare our forecast to the lesser evil's actual vote shares in Lima. We observe that our out-of-sample point prediction comes fairly close to the real electoral results, suggesting our model performs well in Lima. In 2011, the model is off by 0.83 percent only, because Fujimori obtained 22.75 percent points in Lima and our model predicted 21.92 points. Similarly, in the 2016 election, we are off by 4.12 percent points because PPK garnered 29.63 percent of Lima's votes and our forecast indicated he would obtain 33.75 percent. Even though we do not expect our forecast to perform well nationally given the urban bias of our polling data, we also compare our forecast to the national election outcomes. Not surprisingly, our model under-predicts the vote share of Fujimori by 1.63 points, and over-predicts the vote share of PPK by 12.84 points. The direction and magnitude of the errors are to be expected given that PPK did poorly among non-urban voters, while Fujimori had a more balanced support outside and inside the capital city.

15. It is also possible that the effect of the economy is captured by the presidential approval variable, which could explain why the economic indicator does not reach statistical significance in our model. As Arce and Carrión (2010) have shown, presidential approval in Peru responds to economic performance, in line with standard economic voting models. 
MOISÉS ARCE AND SOFÍA VERA

CHOOSING THE LESSER EVIL: FORECASTING PRESIDENTIAL ELECTIONS IN PERU

Table 5. Predictions

\begin{tabular}{lccccc}
\hline & $\begin{array}{c}\text { Vote share } \\
\text { forecast }\end{array}$ & $\begin{array}{c}\text { Actual vote share } \\
\text { (Lima) }\end{array}$ & $\begin{array}{c}\text { Actual vote } \\
\text { share (Nation) }\end{array}$ & Diff to Lima Diff to Nation \\
\hline $\begin{array}{l}\text { Fujimori 2011 } \\
\text { first round }\end{array}$ & 21.92 & 22.75 & 23.55 & -0.83 & -1.63 \\
\hline $\begin{array}{l}\text { PPK 2016 } \\
\text { first round }\end{array}$ & 33.75 & 29.63 & 20.91 & 4.12 & 12.84 \\
\hline
\end{tabular}

Source: Authors' own elaboration

\section{CONCLUSION}

Peruvian elections are characterized by a high level of volatility and electoral uncertainty. Anything can (and has) happened in recent elections. Despite the fluidity of political personalities without stable party organizations, however, we observe candidate learning and moderation to capture the political center and also a preference for the continuity of the economic model in the context of an unprecedented economic expansion. The weakness of the Peruvian political class also moves potential antiestablishment candidates like Humala to embrace this continuity. This information allows us to identify the candidate who is perceived to do less damage to the status quo while in office, and in turn, apply standard forecasting models to predict the outcome of the elections. Our results show that the popularity of the incumbent president works as a proxy for continuity and support for the lesser evil candidate. Our results on the importance of the economy remain inconclusive.

In every election, Peruvian voters ponder which candidate most aptly moves to the political center (centrism) and who is perceived to be the lesser evil by embracing continuity. There is no doubt this is a delicate balance. In 2011, the three candidates who represented continuity-Kuczynski, Toledo and Castañeda-collectively captured $43.9 \%$ of the vote, but they competed with each other and split the centrist vote. This failure of coordination due to the poor quality of party representation paved the way for a different contest between Humala and Fujimori, candidates who "clearly represented more dramatic deviations from existing policies" (Lupu, 2012, p. 622). In the end, Humala embraced continuity, but only after the election.

With the spread of democracy in Peru, the polling industry has grown considerably, but there is still room for improvement. In our review of the vote intention series for the 2021 presidential election, for instance, we noticed that some polling firms like Datum International and Ipsos Peru logged the name of 
potential presidential contenders almost three years out before the election, but other polling firms like IEP did so much closer to the election date. Moreover, during the election cycle of 2021 it looks like all of these polling firms may have overestimated the likely vote intention of establishment candidates, while underestimating the vote intention of other candidates like Pedro Castillo. "Son of the soil" Castillo faced Keiko Fujimori in the runoff election of June 2021 (Collyns, 2021). Yet vote intention for Castillo was only logged in late 2020 and it stayed within single digits up until March 2021, about a week or so before the election. More consistent reporting and coverage of other candidates across these polling firms would likely improve election forecasting in Peru.

We invite future generations of researchers to revise and refine this basic forecasting model. Future studies could consider ways to identify the lesser evil far enough in advance of elections. While we provided a definition of the lesser evil - the centrist candidate who will maintain the current economic model - to overcome the challenge of dealing with a large number of parties and the frequent emergence of new actors, the difficulty in categorizing the lesser evil candidates sufficiently early remains a limitation of the present work. Nevertheless, this shortcoming is inevitably driven by the volatile nature of the Peruvian electoral scene, where political parties are weak and non-programmatic. Given this reality, forecasters might be forced to wait for the electoral campaign opening to observe candidate proposals and assign the "lesser evil" label. Still, we believe that constructing the dependent variable in this way is a productive exercise because it allows us to test forecasting models in a least-likely setting for predicting elections, which to our knowledge, has not been done before in Peru.

To move beyond our parsimonious model, future research on forecasting elections in Peru should consider subjective evaluations of the economy, which may be better predictors of the health of the economy than the indicators we use. Future work should also consider the policy preferences of voters as well as the salience of other non-economic issues. To be clear, our study primes the continuation of the economic model because of this extraordinary period of economic expansion characterized as the "Peruvian miracle" (Mendoza, 2013). Other voter concerns are likely to be important in other contexts, especially in the postpandemic era. ${ }^{16}$ On this subject, the COVID-19 pandemic dealt a huge blow to the Peruvian economy and has wiped out the social and economic gains attributed to the commodity boom. Periods of economic crisis have always been a harbinger

16. In a context of economic crisis, identifying the lesser evil candidate could also be more difficult. The time scope of our work is circumscribed to a context of economic expansion when the candidates had strong incentive to moderate and seek to represent the continuity of an economic model that appeared to be working for many. Nevertheless, in the months leading up to the 2021 election a clear frontrunner did not appear and the pandemic revealed unresolved economic and social inequalities. 
for change in the Latin American region, and the Peruvian presidential election of 2021 will not be an exception. If our arguments favoring a political cleavage around the candidates representing centrism and continuity hold, Peruvians will again decide their vote on for or against the candidate who is likely to do the less damage to the status quo while in office. If they do not, Peruvian voters may face an electoral cycle with a wide range of possible outcomes.

\section{REFERENCES}

Anderson, C. J. (2000). Economic Voting and Political Context: A Comparative Perspective. Electoral Studies, 19(2-3), 151-170.

Arce, M. (2003). Political Violence and Presidential Approval in Peru. Journal of Politics, 65(2), 572-583.

Arce, M. (2005). Market Reform in Society: Post-crisis Politics and Economic Change in Authoritarian Peru. Pennsylvania State University Press.

Arce, M. (2014). Resource Extraction and Protest in Peru. University of Pittsburgh Press.

Arce, M. and Incio, J. (2018). Perú 2017: Un caso extremo de gobierno dividido. Revista de Ciencia Política, 38(2), 361-377.

Arce, M., and Carrión, J. (2010). Presidential Support in a Context of Crisis and Recovery in Peru, 1985-2008. Journal of Politics in Latin America, 2(1), 31-51.

Banco Central de Reserva del Perú. (2021). Estadísticas. https://www.bcrp.gob.pe/estadisticas.html

Bartels, L. M. and Zaller, J. (2001). Presidential Vote Models: A Recount. PS: Political Science and Politics, 34(1), 9-20.

Bril-Mascarenhas, T. (2012). Peru: The Center Could Not Hold. Berkeley Review of Latin American Studies, Fall-Winter, 12-15.

Bunker, K. (2020). A Two-stage Model to Forecast Elections in New Democracies. The International Journal of Forecasting, 36(4), 1407-1419.

Bunker, K, and Bauchowitz, S. (2016). Electoral Forecasting and Public Opinion Tracking in Latin America: An Application to Chile. Revista de Ciencia Política, 54(2), 207-233.

Cantú, F., Hoyo V. and Morales, M. A. (2015). The Utility of Unpacking Survey Bias in Multiparty Elections: Mexican Polling Firms in the 2006 and 2012 Presidential Elections. International Journal of Public Opinion Research, 28(1), 96-116.

Collyns, D. (2021, May 5). Son of the Soil Pedro Castillo Promises a Presidency for Peru's Poor. The Guardian. https://www.theguardian.com/global-development/2021/ may/05/pedro-castillo-peru-presidential-candidate

Cotler, J. (2011). Capitalismo y democracia en el Perú: La tentación autoritaria. In L. Pásara, (Ed.), Perú: ante los desafíos del siglo XXI (pp. 519-555). Fondo Editorial de la Pontifica Universidad Católica del Perú.

Dargent, E. (2015). Technocracy and Democracy in Latin America: The Experts Running Government. Cambridge University Press.

Dargent, E. and Muñoz, P. (2016). Peru: A Close Win for Continuity. Journal of Democracy, 27(4), 145-158. 
Fiorina, M. P. (1981). Retrospective Voting in American National Elections. Yale University Press.

Freeman, W. and McClintock, C. (2021, June 10). Why Peru's Next Leader Was Elected by Less Than 1 Percent Margin. The Washington Post. https:// www.washingtonpost.com/politics/2021/06/10/why-perus-next-leaderwas-elected-by-less-than-1-percent-margin/

Instituto Nacional de Estadística e Informática. (2021). Economía. https://www.inei.gob. pe/estadisticas/indice-tematico/economia/.

James, G., Witten, D., Hastie, T. and Tibshirani, R. (2013). An Introduction to Statistical Learning. Vol. 112. Springer.

Jennings, W., Lewis-Beck, M., and Wlezien, C. (2020). Election Forecasting: Too Far Out? International Journal of Forecasting, 36(3), 949-962.

Kelly, J. M. (2003). Counting on the Past or Investing in the Future? Economic and Political Accountability in Fujimori's Peru. Journal of Politics, 65(3), 864-880.

Kuhn, M., and Johnson, K. (2013). Applied Predictive Modeling. Vol. 26. Springer.

La República. (2021, February 1). George Forsyth y Verónika Mendoza lideran intención de voto, según IEP. https://larepublica.pe/elecciones/2021/01/31/george-forsythy-veronika-mendoza-lideran-intencion-de-voto-segun-iep-pltc/

Leiteritz, R. J. (2010). Sustaining Open Capital Accounts: International Norms and Domestic Institutions; A Comparison between Peru and Colombia. Doctoral dissertation, London School of Economics.

Levitsky, S. (2013). Peru: The Challenges of a Democracy without Parties. In J. I. Domínguez and M. Shifter (Eds), Constructing Democratic Governance in Latin America (pp 282-315). Johns Hopkins University Press.

Levitsky, S., and Cameron, M. A. (2003). Democracy without Parties? Political Parties and Regime Change in Fujimori's Peru. Latin American Politics and Society, 45(3), 1-34.

Lewis-Beck, M. S. (2005). Election Forecasting: Principles and Practice. The British Journal of Politics and International Relations, 7(2), 145-164.

Lewis-Beck, M. S. and Stegmaier, M. (2007). Economic Models of Voting. In R. Dalton and H.-D. Klingemann (Eds.). The Oxford Handbook of Political Behavior (pp. 518-537). Oxford University Press.

Lewis-Beck, M. S. and Tien, C. (2012). Election Forecasting in Turbulent Times. PS: Political Science and Politics, 45(4), 625-629.

Lupu, N. (2012). The 2011 General Election in Peru. Electoral Studies, 31, 621-624.

Mendoza, W. (2013). Peruvian Miracle: Good Luck or Good Policies?. Documentos de Trabajo/Working Papers, 371. Pontificia Universidad Católica del Perú.

O'Boyle, B. (2020, August 19). This Soccer Star Could be Peru's Next President. Americas Quarterly. https://americasquarterly.org/article/this-soccer-star-could-be-perusnext-president/

ONPE (Oficina Nacional de Procesos Electorales). (2021). Elecciones. https://www.onpe. gob.pe/elecciones/

Ponce Acuña, R. (2011, June 11). Presidente de CONFIEP: Humala tiene bastante sentimiento social [Video]. Youtube. https://www.youtube.com/watch?v=m_qaY-F8WYQ 
RPP. (2011, June 6). Bolsa de Valores de Lima registró la peor caída de su historia. https:// rpp.pe/economia/economia/bolsa-de-valores-de-lima-registro-la-peor-caida-de-suhistoria-noticia-372872

Sanders, D. (2005). Popularity Function Forecasts for the 2005 UK General Election. The British Journal of Politics and International Relations, 7(2), 174-190.

Serrano, A. and Navarro, Ó. (2017, October 27).¿Por quélas encuestas no aciertan en América Latina? CELAG. https://www.celag.org/las-encuestas-no-aciertan-america-latina/

Schmidt, G. D. (2003). The 2001 Presidential and Congressional Elections in Peru. Electoral Studies, 22, 325-395.

Schmidt, G. D. (2007). Back to the Future: The 2006 Peruvian General Election. Electoral Studies, 26, 797-837.

Schmidt, G. D. (2012). AIDS or Cancer?: The 2011 Peruvian Elections. Electoral Studies, 31, 624-628.

Schmidt, Gregory D. (2016). A Split Decision: The 2016 Peruvian General Election and Presidential Runoff. Electoral Studies, 44, 445-464.

Stegmaier, M., and Lewis?Beck, M. S. (2009). Learning the Economic Vote: Hungarian Forecasts, 1998?2010. Politics and Policy, 37(4), 769-780.

Stegmaier, M. and Lewis-Beck, M. S. (2013). Economic Voting. In R, Valelly, (Ed), Oxford Bibliographies in Political Science. Oxford University Press. https://doi.org/10.1093/ obo/9780199756223-0057

Stegmaier, M. and Norpoth, H. (2013). Election Forecasting. In R. Valelly (Ed.), Oxford Bibliographies in Political Science. Oxford University Press.

Stegmaier, M., and Williams, L. K. (2016). Forecasting the 2015 British Election through Party Popularity Functions. Electoral Studies, 41, 260-63.

Stokes, S. C., Przeworski, A., Buendía J., and Wolfson, L. (1997). Opinión pública y reformas de mercado: Las limitaciones de la interpretación económica del voto. Desarrollo Económico, 37(145), 31-56.

Tanaka, M. (2011). Peru's 2011 Elections: A Vote for Moderate Change. Journal of Democracy, 22(4), 75-83.

Turgeon, M., and Rennó, L. (2012). Forecasting Brazilian Presidential Elections: Solving the N Problem. International Journal of Forecasting, 28(4), 804-12.

Vergara, A. and Encinas, D. (2016). Continuity by Surprise: Explaining Institutional Stability in Contemporary Peru. Latin American Research Review, 51(1), 159-180.

Walther, D. (2015). Picking the Winner(s): Forecasting Elections in Multiparty Systems. Electoral Studies, 40, 1-13.

Williams, L. V., and Reade, J. J. (2016). Forecasting Elections. Journal of Forecasting, 35(4), 308-28. https://doi.org/10.1002/for.2377

World Bank. (2021). World Bank Open Data. Peru. https://data.worldbank.org/indicator/ NY.GDP.PCAP.KD?locations=PE 


\section{APPENDIX}

\section{Appendix A. Descriptive statistics}

Table A1. Summary statistics

\begin{tabular}{lccccc}
\hline \multicolumn{1}{c}{ Variable } & Mean & St. Dev. & Min & Max & N \\
\hline Lesser evil & 22.06 & 10.15 & 4.00 & 50.10 & 113 \\
\hline GPD growth & 4.28 & 5.35 & -39.93 & 14.02 & 345 \\
\hline Inflation & 0.24 & 0.29 & -0.53 & 1.30 & 348 \\
\hline Mining GDP growth & 4.39 & 8.60 & -45.61 & 33.02 & 347 \\
\hline Presidential approval & 35.96 & 19.01 & 6.00 & 87.00 & 341 \\
\hline
\end{tabular}

Source: Authors' own elaboration

\section{Appendix B. Vote intention data coverage}

Table A2 shows the time coverage of vote intention data by election. We collected data leading up to 5 first round elections (2000, 2001, 2006, 2011, 2016, 2021) and 3 runoff elections (2006, 2011, and 2016).

Table A2. Vote intention observations by election

\begin{tabular}{lccc}
\hline \multicolumn{1}{c}{ Election } & Dates & $\begin{array}{c}\text { Number of } \\
\text { months }\end{array}$ & $\begin{array}{c}\text { Number of } \\
\text { polls }\end{array}$ \\
\hline 2000 (first round) & March 2000 - April 2000 & 2 & 2 \\
\hline 2001 (first round) & January 2001 - April 2001 & 4 & 22 \\
\hline 2006 (first round \& runoff) & September 2002 - June 2006 & 19 & 55 \\
\hline 2011 (first round \& runoff) & August 2008 - May 2011 & 12 & 24 \\
\hline 2016 (first round \& runoff) & July 2014 - June 2016 & 16 & 28 \\
\hline 2021 (first round) & December 2017 - September 2020 & 33 & 50 \\
\hline Total & & 86 & 181 \\
\hline
\end{tabular}

Source: Authors' own elaboration 


\section{Appendix C. Data sources}

Table A3. Data sources

\begin{tabular}{|c|c|c|c|}
\hline Variable & Frequency & Sources & Measurement \\
\hline Lesser evil & $\begin{array}{l}\text { Bi-monthly } \\
\text { or irregular }\end{array}$ & $\begin{array}{l}\text { Ipsos-Peru, IEP, Datum, } \\
\text { Universidad de Lima, CPI, } \\
\text { Imasen }\end{array}$ & $\begin{array}{l}\text { Monthly average of raw } \\
\text { polls. "If the general elections } \\
\text { were held tomorrow, which } \\
\text { candidate would you vote } \\
\text { for." }\end{array}$ \\
\hline GPD growth & Monthly & $\begin{array}{l}\text { Instituto Nacional de } \\
\text { Estadística e Información- } \\
\text { INEI }\end{array}$ & \\
\hline Inflation & Monthly & $\begin{array}{l}\text { Banco Central de Reserva } \\
\text { del Peru-BCRP }\end{array}$ & \\
\hline $\begin{array}{l}\text { Mining GDP } \\
\text { growth }\end{array}$ & Monthly & $\begin{array}{l}\text { Banco Central de Reserva } \\
\text { del Peru-BCRP }\end{array}$ & \\
\hline $\begin{array}{l}\text { Presidential } \\
\text { approval }\end{array}$ & Monthly & Ipsos-Peru & $\begin{array}{l}\text { "In general, would you } \\
\text { say that you approve or } \\
\text { disapprove of the president } \\
\text { [name]'s administration?" }\end{array}$ \\
\hline
\end{tabular}

Source: Authors' own elaboration 